\title{
Transition to Certification Schemes and Implications for Market Access: GlobalGAP Perspectives in Kenya
}

\author{
Isaac Maina Kariuki \\ Department of Agricultural Economics and Business Management, Egerton University, Egerton, Kenya \\ Email: waki gaga@yahoo.de
}

Received 26 August 2014; revised 27 September 2014; accepted 14 October 2014

Copyright (C) 2014 by author and Scientific Research Publishing Inc.

This work is licensed under the Creative Commons Attribution International License (CC BY).

http://creativecommons.org/licenses/by/4.0/

cC) (i) Open Access

\begin{abstract}
Voluntary pre-farm certification schemes especially GlobalGAP are increasingly defining market access for smallholders in developing countries. Their strict demand for financial and technical competencies and concerns for producer welfare and environmental conservation imply that transition to certified production could spell smallholders' exit or shift to alternative markets for no-compliance. But what factors motivate successful transition to certification and does alternative market access exist for the unsuccessful transition? Multinomial logit estimates reveal training and higher farm assets base as key indicators of successful certification and organized production. However, a large cultivated land resource favours certification but disfavours transition to organized production. The results point to sensitivity of certification schemes to expertise on technical information and assets that enhance cultivation of quality, reliable and hygienic produce and economies of scale in farming. The transition to organized production seems efficient if technical knowledge and assets that enhance cultivation of quality, reliable and hygienic produce are present. The results imply that farmer expertise, farm assets and land resource are critical barriers for farmers transiting to certification schemes. This calls for concerted mitigation if smallholders in developing countries are to benefit from the lucrative premium markets in Western Europe.
\end{abstract}

\section{Keywords}

Certification, Market Access, Quality, Smallholders, Developing Countries, Kenya

\section{Introduction}

The food sector is increasingly facing quality assurance standards (QAS) requiring third party certification of 
production, manufacturing or service delivery practices in international trade. This is motivated partly by food scares (e.g., dioxin), public concerns about microbiological and pesticide residue risks in food and food safety failure that increase health cost burden on Western national governments [1]-[4]. As a result, there is more control on food quality, hygiene and safety from the farm to the table [5] [6]. The trend of controlling food quality, hygiene and safety will gain momentum because of increased trade in fresh fruit and vegetables (FFV) and emerging food risks (e.g., Enterohaemorrhagic Escherichia coli and Schmallenberg virus). Firms and farms adopt QAS for varied reasons such as price premiums, cost reductions, reputation and image building, market access and vertical coordination [7]. Other QAS motivators include health and welfare benefits, environmental care, and satisfaction of consumers [8] [9]. However, the principal disincentives to adopt QAS are increased production and compliance costs, lack of visibility at the consumer level and increased duplication in the same chain [7] [10]. Adoption studies show that QAS are size responsive, human capacity demanding and dependent on the attitude of the adopter [11]-[13]. Scale economies are argued to enhance farmers' capabilities to implement cropping patterns, traceability and quality management systems [14]. Some evidence show considerable support for farmer based organizations, market characteristics and market linkages in bridging the gap among smallholder and resource constrained adopters [15]-[17]. Empirical studies on adoption of QAS have used the binary choice approach e.g., [18]-[21] although factor, discriminant and cluster analysis, and qualitative survey interviews are evident, see [15] [22]-[25]. Most of these studies consider adoption as a one off event. In this article, certification is conceptualized as a transition process where independent farmers decide to form a producer group and then a producer group seeks compliance with certification control points. The article utilizes a multinomial logit model to analyze whether training, farm assets, traceability and land resources motivate smallholders to successfully adopt GlobalGAP (GGAP) certification (previously EUREPGAP) in the production of French beans in Kenya. It also shows how unsuccessful certification creates opportunity for farmers to serve less quality demanding markets.

\section{Background to Export Horticulture and GGAP in Kenya}

In most African economies, agriculture constitutes a large share of the national income and employment [26]. However, because of poor farming technologies, low access to farm credit and thin or missing markets rural areas face low farm incomes. One strategy used to ameliorate farm incomes, adoption of technologies and market access is irrigated export horticulture crop production through small scale irrigation schemes or government controlled commercial schemes [27]. The popular model links producers with a marketer preferably an export firm through a contract specifying the crop, inputs and amount of output to deliver at a later date at an agreed price [28] [29]. Apart from bridging idiosyncratic market failure in farm inputs, use of marketers co-opts smallholders into international markets. The low labor costs and comparative advantage in the supply of field crops that require minimal agronomic activities favor smallholders in fresh produce markets [30]. The main focus for horticultural production has been mainly because of high value to volume ratio, short gestation period and higher incomes per area compared to cereals [31].

However, besides recording high post-farm produce loses due to perishability, the FFV sector poses health and environmental threats from plant protection products used to control pests, diseases and obnoxious weeds [32] [33]. Further, there has been a shift to producers with the ability to implement traceability and to maintain consistency and reliability of supplies [14] [30]. Concentration at the export and retail markets is also gradually increasing where few firms with dominant market power control trade [34]. Within FFV supply chains, demand for standardized farm practices is dominating market access [29] [10]. Since its establishment in 1997, GGAP certification is the most widely demanded pre-farm scheme by Western European retailers [35]. GGAP suppliers are required to show evidence of upfront farm equipment and structures, soil, water and pesticide residue testing, and quality management system to receive a certificate of compliance [35]. Besides enhancing market access, GGAP offers farmers opportunities for improved personal health, environmental conservation, and acquisition of good management skills [36]. However, because of organizational, financial and technical constraints, smallholders miss on certification and either exit export crop production or switch into other enterprises [25] [37]. GGAP featured in Kenya in 2003 with a requirement for full compliance of all FFV exporters to the European Union. Earlier reported statistics show that by 2006, 352 Kenyan producer groups were certified and while other documents cite 2569 GGAP certified farms in Kenya consisting of 69 large scale farms, 207 medium scale farms, and 229 small scale farms for 56 grower groups, the current statistics show that there are 580 certified in- 
dividual producers and 6 producer groups [38]-[40]. Despite strict quality requirements, the international trade in Kenya's French beans with European markets has over the last decade increased from 21,661 tonnes in 2002 to 37,855 tonnes in 2012 [41]. This article is therefore an empirical analysis of two questions: Do needs for training, farm assets, traceability and land resources motivate successful transition to certification? What alternatives exist for the unsuccessful? The article contributes to the increasing debate on QAS in international trade and their effects on smallholders in developing countries.

The rest of the paper is structured as follows. In Section 2, a conceptual model of GGAP certification is presented and data described in Section 3. Section 4 contains the empirical results and discussions. The final section summarizes and concludes the results.

\section{Conceptual Model for Successful Adoption of GGAP}

Smallholders are certified under option 2 for producer groups after compliance with farm audits on critical control points through issuance of a certificate paid at cost [40]. Within a group, individual farmers are responsible for own plots and the requirements thereof. Land size passes for wealth if it is not significantly too small to deny possible inclusion of producers in pooled activities [20]. Further, group formation requires cohesive members within manageable distances to ease establishment of a quality management system [35] [42]). Intuitively, it is easier to mobilize farmers that share a common buyer or, already organized groups in villages at low search and administrative costs than independent farmers [43]. Technically, all farmers are required to meet at least minimum level of control points for compliance criteria on on- and off-farm good hygiene practices, pesticides use, control and disposal and record keeping either through private or public training [25]. A farmer should have essential farm assets; a calibrated sprayer and pesticides protective equipment (PPE), on-farm grading shed and a toilet for post-harvest crop care [35]. Evidence of produce traceability in the immediate supply chain is also required [29] [34]. Besides meeting GGAP requirements, smallholders might be motivated to adopt certification by an expected price premium, market pressure and reputation [25] [44]. We use the number of seasons with a buyer as a proxy for market pressure and reputation. Through repeated exchanges, a buyer seeking a stable source of quality, hygienic and safe supplies for Western European retailers would impress producers to get certified. Further, the age and schooling of a producer affects the propensity to adopt innovations. Either, younger and more educated producers might embrace new production methods more easily than older less educated ones or older less educated farmers might be more trusted to agree to a hold-up situation introduced by certification. Additionally, market linkage could influence adoption. For instance, export firms have more financial and technical expertise than intermediaries and might dictate targeting of certified markets [30]. Finally, given that access to irrigation water, producer health and on- and off-farm crop hygiene are critical for the production of consistent, reliable and hygienic beans, we use a water pump, PPE and on-farm grading shed to proxy these attributes.

Smallholders are basically heterogeneous in terms of risk-averse behaviour, productivity, and reservation utility. Therefore, in the new quality markets GGAP certification is assumed to satisfy some latent utility which independent and organized production cannot. We further assume that independent farmers meet the minimum market quality standard but the variation in quality changes if farmers are organized or GGAP certified. That means the market might have high or premium quality from organized or GGAP certified farmers respectively. This distinction is based on the fact that Western European retailers have varying degrees of strictness on quality standards. Further, since wholesalers target mass consumer markets and retailers, high care consumer markets we expect quality variations. This intuition allows us to avoid capturing the cheating of quality across producers. Consequently, GGAP certification is modeled as a multinomial choice problem involving transition from independent, group to certified group producers.

Formally, a random utility model is assumed [45]. Smallholders maximize utility by choosing either to produce as a certified producer group, producer group or independently. Let the level of indirect utility associated with either choice be a latent variable, $G_{k}^{*}$. This is mathematically expressed as $G_{k}^{*}=X^{\prime} \beta_{k}+\varepsilon_{k}$ where $X$ is a vector of characteristics and $\beta_{k}$ is a vector of coefficients pertaining to method $k$ and $\varepsilon_{k}$ is a random error term [45]. We observe $G_{k}$ where,

$$
G_{k}=\left\{\begin{array}{rr}
1, & G_{k}^{*}=\max \left[G_{1}^{*}, \cdots, G_{3}^{*}\right] \\
0, & \ldots \ldots \ldots \ldots, \text { otherwise }
\end{array}\right\}
$$


Further, a smallholder is assumed not to be indifferent between two methods. If the residuals $\varepsilon_{k}$ are independently and identically distributed (i.i.d.) and have an extreme value distribution with a cumulative distribution function given by,

$$
F\left(\varepsilon_{k}<l\right)=\exp \left(-e^{-l}\right), k=1, \cdots, K
$$

It follows that the probability of choosing method, $k p\left(G_{k}=1 \mid X\right)$ can be expressed as

$$
p_{k}=\frac{\exp \left(X^{\prime} \beta_{k}\right)}{\sum_{k^{\prime}}^{K} \exp \left(X^{\prime} \beta_{k^{\prime}}\right)}, k=1, \cdots, n-1
$$

Conceptually, let the latent utility from certification be, $G^{c}$, organized production, $G^{o}$ and independent production, $G^{i}$. Certification is observed if, $G^{c}>G^{o}>G^{i}$. Following equation (1), the observed choice can be represented as a linear function

$$
G_{i k}^{*}=\alpha_{i k}+\delta V_{i k}+\gamma W_{i k}+\eta X_{i k}+\varphi Z_{i k}+\varepsilon_{i k}
$$

where $\alpha_{i k}$ is the smallholder specific intercept representing the intrinsic propensity of producer $i$ for choice method $k$, while $V_{i k}, W_{i k}, X_{i k}$, and $Z_{i k}$ are vectors of training, farm assets, traceability and land covariates respectively. The error term, $\varepsilon_{i k}$ is i.i.d, has a $c d f$ as shown in Equation (2) and is orthogonal to the distribution of $\alpha_{i k}$ [46]. The error term captures the additive nature of unobserved explanatory variables to the observed choice. Following Equation (3), a smallholder chooses method $k$ over alternative $k^{\prime}$ if $G_{i k}^{*}>G_{i k^{\prime}}^{*}$. If $Y_{i}(k=0,1,2)$ is taken as an indicator variable denoting the actual choice, the resulting choice probabilities are

$$
\begin{aligned}
& \operatorname{Pr}\left(Y_{i}=k \mid \alpha_{i k}, V_{i k}, W_{i k}, X_{i k}, Z_{i k}\right)=\frac{\exp \left(\alpha_{i k}+\delta V_{i k}+\gamma W_{i k}+\eta X_{i k}+\varphi Z_{i k}\right)}{\sum_{k^{\prime}=1}^{K} \exp \left(\alpha_{i k^{\prime}}+\delta V_{i k^{\prime}}+\gamma W_{i k^{\prime}}+\eta X_{i k^{\prime}}+\varphi Z_{i k^{\prime}}\right)}, \\
& k=1, \ldots, n-1
\end{aligned}
$$

The multinomial logit model in Equation (5), is estimated after normalizing the estimation parameters $\alpha, \delta$, $\gamma, \eta$ and $\varphi$ by equating them to zero. The following log likelihood function is consequently maximized,

$$
\ln L=\sum_{i=1}^{n} \sum_{k=1}^{K} Y_{i k} \ln \left[\frac{\exp \left(\alpha_{i k}+\delta V_{i k}+\gamma W_{i k}+\eta X_{i k}+\varphi Z_{i k}\right)}{\sum_{k^{\prime}=1}^{K} \exp \left(\alpha_{i k^{\prime}}+\delta V_{i k^{\prime}}+\gamma W_{i k^{\prime}}+\eta X_{i k^{\prime}}+\varphi Z_{i k^{\prime}}\right)}\right]
$$

\section{Data Sources and Descriptive Statistics}

The data come from Mwea Tebere, Kirinyaga, Kenya. This is an irrigated rice scheme with access to good roads, horticulture handling facilities, and a high producer of horticulture especially French beans. A total of 249 smallholder farmers were sampled from 24 villages and interviews conducted in the months of April through June 2006 using a short questionnaire. The principal question addressed whether a farmer was independent or a member of a producer group and if in a producer group, whether they were GGAP certified. The collected data included farmer-training competencies, farm assets, traceability, land resources and other socio-economic characteristics. In Table 1, the descriptive statistics are presented to differentiate farmers in terms of farm structure and certification. There are 149 independent farmers, 100 farmers in organized producer groups 72 of which are in certified and 28 in non-certified producer groups ${ }^{1}$.

Comparisons are made between independent farmers and those in producer groups, those in certified and non certified producer groups. Except for the delivery date between farmers in certified and non certified producer groups, all the training, farm assets, traceability and certification requirements are significant at between $1 \%$ and $10 \%$ levels. Independent farmers have very low compliance on record keeping, post harvest crop care, investment on on-farm grading shed and protective gear and use of farm identification codes. Farmers in producer groups have complete training on pesticides use, application and control, crop and personal hygiene, and record keeping and post harvest crop care. They all invest in a calibrated sprayer. Across the comparisons, all farmers identify produce through the harvested grade. Of the famers in producer groups, $72 \%$ are certified. Thus, com-

\footnotetext{
${ }^{1}$ There are 4 certified producer groups with 10,14, 19 and 29 farmers and 2 non-certified producer groups with 13 and 15 farmers. The
} groups were formed between 2000 and 2005. 
Table 1. Distinct variations conditional on farm structure and certification $(\mathrm{N}=249)$.

\begin{tabular}{|c|c|c|c|c|}
\hline & $\begin{array}{l}\text { Independent Producers } \\
\qquad(\mathrm{N}=149)\end{array}$ & $\begin{array}{c}\text { Producer Groups (PGs) } \\
\qquad(\mathrm{N}=100)\end{array}$ & $\begin{array}{l}\text { Non Certified PGs } \\
\qquad(\mathrm{N}=28)\end{array}$ & $\begin{array}{l}\text { Certified PGs } \\
\quad(\mathrm{N}=72)\end{array}$ \\
\hline GGAP Requirements & Mean (sd) & Mean (sd) & Mean (sd) & Mean (sd) \\
\hline \multicolumn{5}{|l|}{ Training Modules } \\
\hline Pesticides $(0,1)$ & $0.77(0.42)$ & $1(0)^{* * *}$ & $1(0)$ & $1(0)$ \\
\hline Hygiene $(0,1)$ & $0.79(0.41)$ & $1(0)^{* * *}$ & $1(0)$ & $1(0)$ \\
\hline Book keeping $(0,1)$ & $0.33(0.47)$ & $1(0)^{* * *}$ & $1(0)$ & $1(0)$ \\
\hline Post harvest care $(0,1)$ & $0.17(0.37)$ & $1(0)^{* * *}$ & $1(0)$ & $1(0)$ \\
\hline \multicolumn{5}{|l|}{ Farm Assets } \\
\hline Sprayer $(0,1)$ & $0.93(0.25)$ & $1(0)^{* * *}$ & $1(0)$ & $1(0)$ \\
\hline Farm shed $(0,1)$ & $0.13(0.34)$ & $0.98(0.14)^{* * *}$ & $0.93(0.26)$ & $1(0)^{* *}$ \\
\hline Water pump $(0,1)$ & $0.85(0.36)$ & $0.97(0.17)^{* * *}$ & $0.89(0.31)$ & $1(0)^{* * *}$ \\
\hline Protective gear $(0,1)$ & $0.16(0.37)$ & $0.76(0.43)^{* * *}$ & $0.64(0.49)$ & $0.81(0.40)^{*}$ \\
\hline \multicolumn{5}{|l|}{ Traceability Breadth } \\
\hline Group name $(0,1)$ & $0(0)$ & $1(0)$ & $1(0)$ & $1(0)$ \\
\hline Grade $(0,1)$ & $1(0)$ & $1(0)$ & $1(0)$ & $1(0)$ \\
\hline Own name $(0,1)$ & $0.73(0.44)$ & $0.98(0.14)^{* * *}$ & $0.93(0.26)$ & $1(0)^{* *}$ \\
\hline Farm code $(0,1)$ & $0.23(0.42)$ & $0.61(0.49)^{* * *}$ & $0.89(0.31)$ & $0.50(0.50)^{* * *}$ \\
\hline Delivery date $(0,1)$ & $0.55(0.50)$ & $0.84(0.37)^{* * *}$ & $0.79(0.42)$ & $0.86(0.35)$ \\
\hline
\end{tabular}

$*, * *, * * *$ mean the two-sample $\mathrm{t}$ test is significant at $10 \%, 5 \%$ and $1 \%$ level; Source: Own computation using STATA v. 12 from Mwea Tebere French beans survey, April-June 2006.

pared with independent farmers, those in producer groups are significantly well trained, have higher farm asset base, their farm produce is easier to trace and have opportunity for certification. Except for investment in protective gear and use of farm identification code, farmers in certified producer groups are fully endowed in training modules, farm assets and traceability breadth. Uniquely, produce for farmers in certified producer groups can be identified immediately in the supply chain using the group name, the grade and the name of the farmer. Surprisingly, farmers in non certified producer groups use more of farm codes with immediate buyers in the supply chain than those in certified producer groups. Generally, farmers in producer groups have greater compliance on training, farm assets, traceability and certification than independent farmers. On the other hand, the data suggests that farmers in certified producer groups are more compliant with farm assets and traceability breadth than those in non certified producer groups. Consequently therefore, farmers in non certified producer groups could be treated separately from independent farmers.

In the empirical analysis, complete traceability is defined on the basis of breadth i.e. the information the system records as explained in [47]. Produce is fully traceable if it is identifiable using the grade, farmer name, farm code and produce collection date. Because training perfectly predicts group membership and certification, extension visits are used as proxy. Extension can influence knowledge and understanding of QAS requirements [24]. Farm assets are a count variable for ownership of a water pump, PPE and an on-farm grading shed. An education dummy truncated at 12 years of schooling to represent high school education is used. Table 2 shows statistical differences across farm structures and certification based on extension visits, traceability, farm assets, land resources and other factors that condition successful certification. Farmers in non certified producer groups have statistically more extension visits, traceability counts, and farm assets than independent farmers. Additionally, they have more extension visits than farmers in certified producer groups. On the other hand, farmers in certified producer groups have more farm assets and land resources than farmers in non certified producer groups. Considering the other attributes, farmers in certified producer groups have significantly more trade exchange seasons than those in non certified producer groups. However, farmers in non certified producer groups have more trade exchange seasons than independent farmers. Further, they have a higher producer price, a higher number are linked to the market by an export firm and are older than independent farmers.

While the low number of trade exchange seasons among independent farmers indicates possibilities of fre- 
Table 2. Descriptive statistics based on farm structure and certification ( $\mathrm{N}=249)$.

\begin{tabular}{lccc}
\hline & Independent Farmers, $\mathrm{n}=149$ & Not Certified PGs, $\mathrm{n}=28$ & Certified PGs, $\mathrm{n}=72$ \\
\hline Independent Variables & Mean $(s d)$ & Mean $(s d)$ & Mean $(s d)$ \\
\hline Extension visits & $2.46(4.60)^{* * *}$ & $10.04(2.87)$ & $7.76(2.93)^{* * *}$ \\
Traceability breadth & $2.51(1.1)^{* * *}$ & $3.61(0.74)$ & $3.36(0.70)$ \\
Assets & $1.14(0.74)^{* * *}$ & $2.46(0.88)$ & $2.81(0.40)^{* * *}$ \\
Area under beans (acres) & $0.79(0.50)$ & $0.79(0.72)$ & $1.53(0.77)^{* * *}$ \\
Exchange seasons (count) & $2.58(3.23)^{* * *}$ & $6.46(4.64)$ & $8.21(3.94)^{*}$ \\
No. sharing buyer (count) & $3.4(1.79)$ & $3.5(1.60)$ & $3.64(1)$ \\
Price (KE/3kg) & $67.62(16.04)^{* *}$ & $74.33(7.8)$ & $71.49(8.36)$ \\
Export firm dummy (0,1) & $0.30(0.46)^{* * *}$ & $0.93(0.26)$ & $0.81(0.40)$ \\
No. of buyers & $8.66(3.01)$ & $8.96(2.3)$ & $9.5(1.5)$ \\
Age (yrs) & $40.18(9.25)^{* *}$ & $44.46(11)$ & $43.29(7.06)$ \\
High school dummy $(0,1)$ & $0.40(0.49)$ & $0.5(0.51)$ & $0.57(0.50)$ \\
\hline
\end{tabular}

Note: *,**,*** mean the two-sample $t$ test is significant at 10\%, 5\% and 1\% level; 1USD = 74KE in 2006; Source: Own computation using STATA v.12 from Mwea Tebere French beans survey, April-June 2006.

quent change of buyers over the annual production cycles, farmers in certified producer groups have a higher number of trade exchange seasons suggesting stability in market access. Extension visits are also significantly low for independent farmers reflecting high costs of providing technical services to individual than organized farmers. The significance of traceability among farmers in non certified producer groups compared with independent farmers show that the former use traceability probably as a differentiation strategy.

Land resource for farmers in certified producer groups is significantly larger signifying that area under beans might have a positive influence on certification. Independent farmers have lower producer prices than farmers in non certified producer groups reflecting either low demand or intense competition for their supplies. The higher number of farmers in non certified producer groups linked to the market by export firms than independent farmers show that more organized farmers prefer direct access to markets instead of using intermediaries. In addition, farmers in non certified producer groups are older indicating likelihood of more risk-averse behaviour and trust-based relationships in the groups.

\section{Empirical Results and Discussions}

In Table 3, the multinomial logit estimates are reported. The Wald statistic is significant indicating that the model fits the data well.

The number of extension visits positively predicts membership of farmers in certified and non certified producer groups respectively. This result is not surprising since decoding technical information on quality, enhancing group administration and implementing certification requirements demand intense training. Training could potentially align farmers' objectives to those of the chain managers in the certification process. [48] also finds extension to be a critical factor in the adoption of enforcement innovations in quality markets.

Farm assets are also positively correlated with farmers in certified and non certified producer groups. Again, the process of certification needs proper planning on farm investments that are appraised during farm audits. In organized group set up, farmers pool resources and use group goodwill to guarantee each other when acquiring farm equipment. Specifically, the results show that successful certification requires upfront farm assets. First, fresh, quality and safe beans are produced easily if a proper watering regime is implemented. Besides, irrigation of farms breaks seasonality and allows flexibility of production schedules throughout the year. Thus, investing in a water pump shifts full responsibility for the production of quality and safe beans to individual farmers. Secondly, Western retailers concerns about quality and safety of imported farm produce from developing countries revolve around pesticide residues and maximum residue limits. In addition, consumers and pressure groups are interested in the welfare of producers and environmental conservation in the production process in the globe. Among the farm practices that increase residues in fresh vegetables and pose threat to the environment include overdosing crops with pesticides, misapplication, ignoring pre-harvest spraying interval, spillovers and improper 
Table 3. Multinomial logit estimates $(\mathrm{N}=249)$.

\begin{tabular}{lcccc}
\hline & Certified PGs & \multicolumn{3}{c}{ Not Certified PGs } \\
\hline Independent Variables & Coef. (S.E) & $\mathrm{z}$ & Coef. (S.E) & $\mathrm{z}$ \\
\hline Extension visits & $0.336(0.102)$ & $3.29^{* * *}$ & $0.528(0.155)$ & $3.40^{* * *}$ \\
Traceability breadth & $0.020(0.592)$ & 0.03 & $-.289(0.497)$ & -0.58 \\
Farm assets & $5.064(1.679)$ & $3.02^{* * *}$ & $1.722(0.583)$ & $2.96^{* * *}$ \\
Area under beans (acres) & $1.213(0.681)$ & $1.78^{*}$ & $-2.476(0.759)$ & $-3.26^{* * *}$ \\
Control Variables & & & & $3.01^{* * *}$ \\
Exchange seasons (count) & $0.574(0.129)$ & $4.44^{* * *}$ & $0.431(0.143)$ & $-1.85^{*}$ \\
No. sharing buyer (count) & $-0.513(0.431)$ & -1.19 & $-0.648(0.350)$ & $-2.33^{* *}$ \\
Price (KE/3kg) & $-0.156(0.047)$ & $-3.30^{* * *}$ & $-0.119(0.051)$ & 0.43 \\
Export firm dummy_1 & $-2.514(1.755)$ & -1.43 & $0.776(1.805)$ & $-2.16^{* *}$ \\
No. of buyers & $-0.104(1.308)$ & -0.08 & $-2.014(0.933)$ & -1.03 \\
High school dummy_1 & $-1.260(0.730)$ & $-1.73^{*}$ & $-0.752(0.728)$ & -0.97 \\
Age (yrs) & $0.370(0.268)$ & 1.38 & $-0.310(0.320)$ & 1.10 \\
Age squared (yrs) & $-0.005(0.003)$ & -1.59 & $0.004(0.004)$ & 1.04 \\
Intercept & $-9.151(6.938)$ & -1.32 & $10.330(9.963)$ & \\
Wald chi2 (24) & $150.05^{* * *}$ & & & \\
Log pseudolikelihood & -63.71 & & Pseudo R2 = 0.7194 &
\end{tabular}

Note: $* * *, * * *$ mean $10 \%, 5 \%$ and $1 \%$ significant levels; Base cases (Independent production $=0$, all dummies $=0$ ).

disposal. Therefore, PPE is a critical mitigation of personal health hazards and environmental pollution as emphasized in GGAP certification's crop and worker/producer hygiene protocols [35]. Hygiene of post-harvest produce remains a key objective for fresh produce handlers in the horticultural value chain [31]. It is critical to note that microbiological contaminations occur frequently when the produce has left the farm because of numerous handlers and handling points. A sorting and grading shed restricts crop handling to few post-harvest care handlers. Therefore, investing in a grading shed is necessary to promote hygienic sorting and grading of beans and to minimize exposure to scorching sun and dust. Notable is that consistency and reliability of quality, hygienic and safe beans are of essence to maintain product shelves and orders with Western retailers and supermarkets [34]. Our results corroborate [49] argument that upfront assets might aggravate exclusion of small farmers from high value chains.

The other significant factor affecting successful certification is the size of land under beans. As the land under beans increases, a farmer is likely to be in a certified producer group. The surprising result is that the likelihood of a farmer being in a non certified producer group decreases as farm sizes under beans increase. On small farms there are high possibilities of farmers observing good agricultural practices carefully because of commitment from family labor. On the other hand, large farm sizes depend on hired and less committed labor unless well supervised but supply more volumes at low unit production and assembling costs. However, farmers with small farms can be mobilized only at high cost than their counterparts with relatively large farms. The result suggests gravitation toward a minimum farm size for a farmer to qualify for inclusion under producer group certification.

Although tracking the flow of farm produce increases trust and efficiency in the supply chain by enhancing quick detection and correction of quality and safety risks, the coefficient on traceability is not significant. Usually, buyers tend to sort, grade and buy what in their opinion is good quality. Further, it is costly to establish a traceability system.

\section{Control Variables}

The number of exchange seasons with a buyer is highly significant indicating more likelihood of market pressure and reputation to influence certification and producer group foundation. This is considerable given that one year production cycle has at least 3 seasons with a possible 5 seasons with irrigation [50]. The possible explana- 
tion is that repeated interactions between farmers and buyers yield familiarity and intrinsic toward joint management of emerging market challenges such as certification and farm reorganization. As in [51], farmers could capitalize on trust developed through interpersonal relationships to seek support for certification and buyers to equally reciprocate. The same could be opined for farmers who have been in trade exchanges for more seasons to embrace new farming arrangements e.g., organized production, that aim to enhance market access. A proper analysis of these approaches can be found in [52].

A higher price is less likely to influence successful transition to certification or producer groups. Compared with independent farmers, farmers in certified and non certified producer groups seem not to be motivated by a price incentive. This is not unlikely because farmers could adopt GAPs for reputation, access to premium markets and cost reduction [7] [11] [12]. In addition, farmers could join producer groups due to low per unit cost advantages and negotiation power especially on inputs acquisition and shared investments (see [8] [16] [25] [53] for examples).

Compared with independent producers, an increase in the number of farmers sharing a buyer and the number of buyers in the village decreases the likelihood of farmers' membership to non certified producer groups. This result implies that farmers have commonly shared quality information and market access possibilities when sharing a buyer. This has the potential to create unwritten rules of engagement on crop quality, hygiene and safety. On buyers, there are chances that competition for farm produce forces farmers to match quality for market prices thereby reducing the urgency for transition from independent to organized production. Another likely explanation could be the participation of export firms that own farms but only use smallholders produce to supplement their orders. The practice of export firms using supplies from independent farmers for less quality discerning markets or to supplement their supplies for the premium markets regardless is not uncommon [30] [54]. Therefore, such buyers might shy away from sponsoring farmers' certification by virtue of their certification status at their company farms [25]. Alternatively, intermediaries could be key market players and based on their on and off market participation it is likely for them not to venture into high end markets that demand certification or organized production. For instance, [55] singles out intermediaries for the low adoption of good agricultural practices in Kenya's horticultural sector. Another possibility could be proliferation of a knowledgeable and innovative supply base of independent farmers that produce high quality and hygienic beans using certification protocol as a business tool. These are likely to create inertia among buyers to support transition to certification. This suggests that a strong alternative market for non certified produce exists (see [20] [25] [53] [54] for buyers' strategies).

The result on schooling suggesting less likelihood of transition to certification for farmers with higher education is not unexpected. More schooled farmers have off-farm employment opportunities that could hinder their fulltime commitment to a more involving certification scheme like GGAP. Off-farm income could be used to invest in farm assets but certification requires careful attention to production practices which might be left to farm labourers who are likely to underperform without supervision. On the other hand, farmers with lower education are likely to devout themselves into full time farming which favours adoption of farm innovations. This result is consistent with [17] who find full time producers to favor adoption of QAS.

A re-estimation of the multinomial logit by redefining the dependent variable as $1=$ certified and $0=$ not certified show that the estimates are robust i.e., they are not particularly very sensitive to changes in the specification of the dependent variable. However, extension and schooling are no longer significant, age is now significant and buyers variable positive. The results are presented in Table 4 . The model shows $93 \%$ correct classification and returns a statistically significant Wald chi-square.

Farm assets and land resource under beans seem to be the most critical for fresh produce farmers wishing to successfully transit to GGAP certification. Additionally, transition to certification is a lot easier for farmers if they have more trade exchange seasons with a buyer. Interesting though is that a higher producer price is not a motivation for those transiting to certification. Further, transition to certification is more likely for younger than older farmers. This is perhaps due to their risk-taking behaviour or because they engage in farming as a business.

\section{Summary and Conclusions}

Voluntary pre-farm gate certification schemes especially GGAP are increasingly defining market access for smallholders in developing countries. Their strict demand for financial and technical competencies and concerns 
Table 4. Probit model estimates $(1=$ certified, $0=$ not certified $)(\mathrm{N}=249)$.

\begin{tabular}{lccc}
\hline Independent Variables & Coefficient & S. E. & z \\
\hline Extension visits & 0.019 & 0.037 & 0.53 \\
Traceability breadth & 0.106 & 0.225 & $3.45^{* * *}$ \\
Farm assets & 1.593 & 0.461 & $4.89^{* * *}$ \\
Area under beans (acres) & 1.389 & 0.284 & $3.55^{* * *}$ \\
Control Variables & & & -0.71 \\
Exchange seasons (count) & 0.181 & 0.051 & $-2.17^{* *}$ \\
No. sharing buyer (count) & -0.100 & 0.141 & -0.86 \\
Price (KE/3kg) & -0.040 & 0.018 & 1.51 \\
Export firm dummy & -0.570 & 0.666 & -0.82 \\
No. of buyers & 0.789 & 0.521 & $2.49^{* *}$ \\
High school education dummy & -0.236 & 0.287 & $-2.77^{* * *}$ \\
Age (yrs) & 0.283 & 0.114 & $-3.25^{* * *}$ \\
Age squared (yrs) & -0.004 & 0.001 & 2.713 \\
Intercept & -8.830 & & Pseudo R2 $=0.6828$ \\
Wald chi2 (12) & $78.72 * * *$ & -47.50 & \\
Log pseudolikelihood & & &
\end{tabular}

Note: *, **, and *** mean significant at $10 \%, 5 \%$ and $1 \%$ level.

for producer welfare and environmental conservation imply that transition to certified production could spell smallholders' exit or shift to alternative markets for non-compliance. This paper examines training, farm assets, traceability and land resource as success factors in transiting to GGAP certification and the role of exclusion in the development of alternative markets. A multinomial logit is used to determine choice of independent, producer group or certified production among Kenya's French beans producers.

Results predict training, farm assets and land under beans as critical factors in transition to GGAP certification. Although training and farm assets favour alternative production set up under producer groups, land under beans is negative. The results may be construed to mean that production expertise on quality and hygiene and output reliability are considerations in adoption of quality markets' innovations. The unsuccessful producer groups compete favourably for the quality markets through training and farm assets. Further, independent farmers compete well based on land area under beans, sharing of buyers, price incentive, competition for supplies and an educated farming community.

To conclude, the paper provides empirical evidence on the role of training, farm assets and land resource in successful certification and subsequently, access to premium markets for smallholders in developing countries. Therefore, certified groups should be incentivized through credit linked asset acquisition schemes. Additionally, less strict markets for independent farmers are shown to exist based on scale economies, shared market outlets, incentives, vibrant competition and an elitist farm business. There is however, need for further research to probe the marketing activities of non-certified producer groups and independent farmers to explain their role in alternative markets, why some producer groups do not seek certification and the inertia to shift into organized production by smallholders.

\section{Acknowledgements}

This survey was funded by German Academic Exchange Services (DAAD, Bonn and Nairobi), and facilities provided by University of Kiel, Germany and Egerton University, Kenya.

\section{References}

[1] Burton, M. and Young, T. (1996) The Impact of BSE on the Demand for Beef and Other Meats in Great Britain. Applied Economics, 28, 687-693. http://dx.doi.org/10.1080/000368496328434 
[2] World Health Organization. (1998) Food Safety and Globalization of Trade in Food: A Challenge to the Public Health Sector. WHO/FSF/FOS/97.8 Rev 1.

[3] Verbeke, W. (2001) Beliefs, Attitudes and Behavior towards Fresh Meat Revisited after the Belgian Dioxin Crisis. Food Quality and Preference, 12, 489-498. http://dx.doi.org/10.1016/S0950-3293(01)00042-8

[4] World Bank. (2005) The Impact of Food Safety and Agricultural Health Standards on Developing Country Exports. Agriculture and Rural Development, Washington DC.

[5] Commission of European Communities (2004) Regulation EC No. 852/2004 of the European Parliament and of the Council of 29th April 2004 on the hygiene of foodstuffs. Official Journal of the European Union, 139.

[6] Commission of European Communities (2006) Regulation (EC) No 178/2006 of 1 February 2006 Amending Regulation (EC) No 396/2005 of the European Parliament and of the Council on Residue Limits in Fresh Fruit and Vegetables. Official Journal of the European Union, 29.

[7] Hobbs, J.E. (2003) Incentives for the Adoption of Good Agricultural Practices. Background Paper for the FAO consultation on Good Agricultural Practices, November 10-12, Rome.

[8] Boselie, D. and van de Kop, P. (2004) Institutional and Organizational Change in Agri-Food Systems in Developing and Transitional Countries: Identifying Opportunities for Smallholders. Regoverning Markets Global Issue Paper 2. IIED.

[9] Fouayzi, H., Caswell, J.A. and Hooker, N. (2006) Motivations of Fresh-Cut Produce Firms to Implement Quality Management Systems. Review of Agricultural Economics, 28, 132-146. http://dx.doi.org/10.1111/j.1467-9353.2006.00277.x

[10] Minae, S., Casey, S., Poisot, A.S., Santacoloma, P. and Termine, P. (2006) Capacity Building and Awareness-Raising on SARD and GAP to Contribute to Food Safety and Quality and Integrated Natural Resources Management in Kenya and Uganda. FAO Mission Report.

[11] Holleran, E., Bredhal, M.E. and Zaibet, L. (1999) Private Incentives for Adopting Food Safety and Assurance. Food Policy, 24, 669-683. http://dx.doi.org/10.1016/S0306-9192(99)00071-8

[12] Jayasinghe-Mudalige, U.K. and Henson, S. (2006) Economic Incentives for Firms to Implement Enhanced Food Safety Controls: Case of the Canadian Red Meat and Poultry Processing Sector. Applied Economic Perspectives and Policy, 28, 494-514. http://dx.doi.org/10.1111/j.1467-9353.2006.00318.x

[13] Jin, S.S. and Zhou, J.H. (2011) Adoption of Food Safety and Quality Standards by China’s Agricultural Cooperatives. Food Control, 22, 204-208. http://dx.doi.org/10.1016/j.foodcont.2010.06.021

[14] Barret, H.R., Ilbery, B.W., Brown, A.W. and Binns, T. (1999) Globalization and the Changing Networks of Food Supply: The Importation of Fresh Horticultural Produce from Kenya into the UK. Transactions of the Institute of British Geographers, 24, 159-174. http://dx.doi.org/10.1111/j.0020-2754.1999.00159.x

[15] Kleinwechter, U. and Grethe, H. (2006) The Adoption of the EurepGAP Standard by Mango Exporters in Piura, Peru. Contributed Paper, The International Association of Agricultural Economists Conference, Gold Coast, Australia, 12-18 August 2006.

[16] Wollni, M. and Zeller, M. (2007) Do Farmers Benefit from Participating in Specialty Markets and Cooperatives? The Case of Coffee Marketing in Costa Rica. Agricultural Economics, 37, 243-248. http://dx.doi.org/10.1111/j.1574-0862.2007.00270.x

[17] Souza Monteiro, D.M. and Caswell, J.A. (2009) Traceability Adoption at the Farm Level: An Empirical Analysis of the Portuguese Pear Industry. Food Policy, 34, 94-101. http://dx.doi.org/10.1016/j.foodpol.2008.07.003

[18] Zuhair, A.H., Green, R. and Herath, D. (2006) An Empirical Analysis of the Adoption of Food Safety and Quality Practices in the Canadian Food Processing Industry. Essays in Honor of Stanley R. Johnson, Article 18.

[19] Karipidis, P., Athanassiadis, K., Aggelopoulos, S. and Giompliakis, E. (2009) Factors Affecting the Adoption of Quality Assurance Systems in Small Food Enterprises. Food Control, 20, 93-98. http://dx.doi.org/10.1016/j.foodcont.2008.02.008

[20] Asfaw, S., Mithöfer, D. and Waibel, H. (2010) What Impact Are EU Supermarket Standards Having on Developing Countries Export of High-Value Horticultural Products? Evidence from Kenya. Journal of International Food and Agribusiness Marketing, 22, 252-276. http://dx.doi.org/10.1080/08974431003641398

[21] Muriithi, B.W., Mburu, J. and Ngigi, M. (2010) Constraints and Determinants of Compliance with EurepGap Standards: A Case of Smallholder French Bean Exporters in Kirinyaga District, Kenya. Agribusiness, 27, 193-204. http://dx.doi.org/10.1002/agr.20261

[22] Henson, S. and Holt, G. (2000) Exploring Incentives for the Adoption of Food Safety Controls: HACCP Implementation in the UK Dairy Sector. Applied Economic Perspectives and Policy, 22, 407-420. http://dx.doi.org/10.1111/1058-7195.00030 
[23] González, A.A. and Nigh, R. (2005) Smallholder Participation and Certification of Organic Farm Products in Mexico. Journal of Rural Studies, 21, 449-460. http://dx.doi.org/10.1016/j.jrurstud.2005.08.004

[24] Chemnitz, C. (2007) The Compliance Decision with Food Quality Standards on Primary Producer Level: A Case Study of the EUREPGAP Standard in the Moroccan Tomato Sector. The Mediterranean Conference of Agro-Food Social Scientists, 103rd EAAE Seminar on Adding Value to the Agro-Food Supply Chain in the Future Euromediterranean Space, Barcelona, 23-25 April 2007.

[25] Graffham, A., Karehu, E. and MacGregor, J. (2007) Impact of EUREPGAP on Access to EU Retail Markets by Small-Scale Growers of Fruits and Vegetables in Kenya. Fresh Insights, No. 6.

[26] World Bank (2011) Africa Development Indicators. World Bank, Washington DC.

[27] Jaffee, S.M. and Little, P.D. (1994) Contract Farming in the Shadow of Competitive Markets: The Experience of Kenyan Horticulture. In: Little, P.D. and Watts, M.J., Eds., Living under Contract: Contract Farming and Agrarian Transformation in Sub-Saharan Africa, The University of Wisconsin Press, Madison, 97-139.

[28] Eaton, C. and Shepherd, A. (2001) Contract Farming: Partnerships for Growth. Food and Agriculture Organization of the United Nations, Rome.

[29] Jaffee, S. and Masakure, O. (2005) Strategic Use of Private Standards to Enhance International Competitiveness: Vegetable Exports from Kenya and Elsewhere. Food Policy, 30, 316-333. http://dx.doi.org/10.1016/j.foodpol.2005.05.009

[30] Jaffee, S. (2003) From Challenge to Opportunity: Transforming Kenyan Fresh Vegetable Trade in the Context of emerging Food Safety and Other Standards. Agriculture and Rural Development Working Paper 10, the IBRD, ARD Department, Washington DC.

[31] Vorley, B. and Fox, T. (2004) Global Food Chains: Constraints and Opportunities for Smallholders. The OECD DAC POVNET, Agriculture and Pro-Poor Growth Task Team, Helsinki Workshop, 17-18 June 2004.

[32] Martinez, M.G. and Poole, N. (2004) The Development of Private Fresh Produce Safety Standards: Implications for Developing Mediterranean Exporting Countries. Food Policy, 29, 229-255. http://dx.doi.org/10.1016/j.foodpol.2004.04.002

[33] Okello, J.J. and Okello, R.M. (2010) Do EU Pesticide Standards Promote Environmentally Friendly Production of Fresh Export Vegetables in Developing Countries? Evidence from Kenyan Green Bean Industry. Environment, Development and Sustainability, 12, 341-355. http://dx.doi.org/10.1007/s10668-009-9199-y

[34] Dolan, C. and Humphrey, J. (2004) Changing Governance Patterns in the Trade in Fresh Vegetables between Africa and the United Kingdom. Environment and Planning A, 36, 491-509. http://dx.doi.org/10.1068/a35281

[35] GlobalGAP (2014) Guidelines and Supporting Documents: Success Factors for Option 2 Implementation. http://www1.globalgap.org/north-america/upload/Standards/IFA/v4_0-1/120306_gg_gr_part_ii_eng_v4_0-1.pdf

[36] Vandergeest, P. (2007) Certification and Communities: Alternatives for Regulating the Environmental and Social Impacts of Shrimp Farming. World Development, 35, 1152-1171. http://dx.doi.org/10.1016/j.worlddev.2006.12.002

[37] Food and Agriculture Organization (1999) The Importance of Food Quality and Safety for Developing Countries. http://www.fao.org/docrep/meeting/x1845e.htm

[38] Moeller, K. (2006) Globalization of the EUREPGAP Standard. Presentation at the EUREPGAP Event for Revision and Implementation 2007, Prague, 21 September. http://www2.globalgap.org/pcspecials.html

[39] Global Horticulture Initiative (2010) Standards and Market Preferences: Opportunities and Constraints. East \& Southern African Video Conference on High Value Horticulture. http://www.globalhort.org/media/uploads/File/Video\%20Conferences/VC3\%20KENYA\%20Position\%20Paper.pdf

[40] GlobalGAP (2014) Database for Producers According to Scheme Requirements. https://database.globalgap.org/globalgap/search/SearchMain.faces

[41] EUROSTAT (2014) Trade Statistics (imports) of Commodity 070820 for 2002-2012 from Kenya (346) into EUR-27. http://exporthelp.europa.eu/thdapp/comext/ComextServlet?

[42] Natural Resources Institute (2003) Focus on Horticulture: Exacting Standards. In: The New Agriculturalist, Natural Resources Institute, Kent.

[43] Place, F., Kariuki, G., Wangila, J., Kristjanson, P., Makauki, A. and Ndubi, J. (2004) Assessing the Factors Underlying Differences in Achievements of Farmer Groups: Methodological Issues and Empirical Findings from the Highlands of Central Kenya. Agricultural Systems, 82, 257-272. http://dx.doi.org/10.1016/j.agsy.2004.07.001

[44] Kariuki, I.M., Loy, J.P. and Herzfeld, T. (2012) Farmgate Private Standards and Price Premium: Evidence from the GlobalGAP Scheme in Kenya's French Beans Marketing. Agribusiness, 28, 42-53. http://dx.doi.org/10.1002/agr.20286

[45] Greene, W.M. (2008) Discrete Choice Modeling. In: Mills, T. and Patterson, K., Eds., The Handbook of Econometrics: Vol. 2, Applied Econometrics, Part 4.2., Palgrave, London. 
[46] McFadden, D. (1984) Econometric Analysis of Qualitative Response Models. In: Grilliches, Z. and Intriligator, M.D., Eds., Handbook of Econometrics, Vol. 2, Elsevier, Armsterdam, 1395-1457.

[47] Golan, E., Krissoff, B., Kuchler, F., Calvin, L., Nelson, K. and Price, G. (2004) Traceability in the U.S. Food Supply: Economic Theory and Industry Studies. Economic Research Service, US Department of Agriculture, Agricultural Economic Report No. 830.

[48] Bellemare, M.F. (2010) Agricultural Extension and Imperfect Supervision in Contract Farming: Evidence from Madagascar. Agricultural Economics, 41, 507-517. http://dx.doi.org/10.1111/j.1574-0862.2010.00462.x

[49] Reardon, T., Barret, C.B., Berdegué, J.A. and Swinnen, J.F.M. (2009) Agrifood Industry Transformation and Small Farmers in Developing Countries. World Development, 37, 1717-1727. http://dx.doi.org/10.1016/j.worlddev.2008.08.023

[50] Minot, N. and Ngigi, M. (2004) Horticulture Development in Kenya and Ivory Coast. The IFRI Workshop on "Successes in African Agriculture”, Lusaka, Zambia, 10-12 June 2002, MTID Discussion Paper No. 73.

[51] Zak, P.J. and Knack, S. (2001) Trust and Growth. The Economic Journal, 111, 295-321. http://dx.doi.org/10.1111/1468-0297.00609

[52] Fischer, E. and Qaim, M. (2012) Linking Smallholders to Markets: Determinants and Impacts of Farmer Collective Action in Kenya. World Development, 40, 1255-1268. http://dx.doi.org/10.1016/j.worlddev.2011.11.018

[53] Ashraf, N., Giné, X. and Karlan, D. (2009) Finding Missing Markets (and a Disturbing Epilogue): Evidence from an Export Crop Adoption and Marketing Intervention in Kenya. American Journal of Agricultural Economics, 91, 973-990. http://dx.doi.org/10.1111/j.1467-8276.2009.01319.x

[54] Ouma, S. (2010) Global Standards, Local Realities: Private Agrifood Governance and Restructuring of the Kenyan Horticulture Industry. Economic Geography, 86, 197-222. http://dx.doi.org/10.1111/j.1944-8287.2009.01065.x

[55] Waweru, A. (2006) Testing a Generic Quality Management System for Smallholders in Kenya. In EUREPGAP’s Prague Presentation on Small Scale Farmers. http://www2.globalgap.org/pcspecials.html 
Scientific Research Publishing (SCIRP) is one of the largest Open Access journal publishers. It is currently publishing more than 200 open access, online, peer-reviewed journals covering a wide range of academic disciplines. SCIRP serves the worldwide academic communities and contributes to the progress and application of science with its publication.

Other selected journals from SCIRP are listed as below. Submit your manuscript to us via either submit@scirp.org or Online Submission Portal.
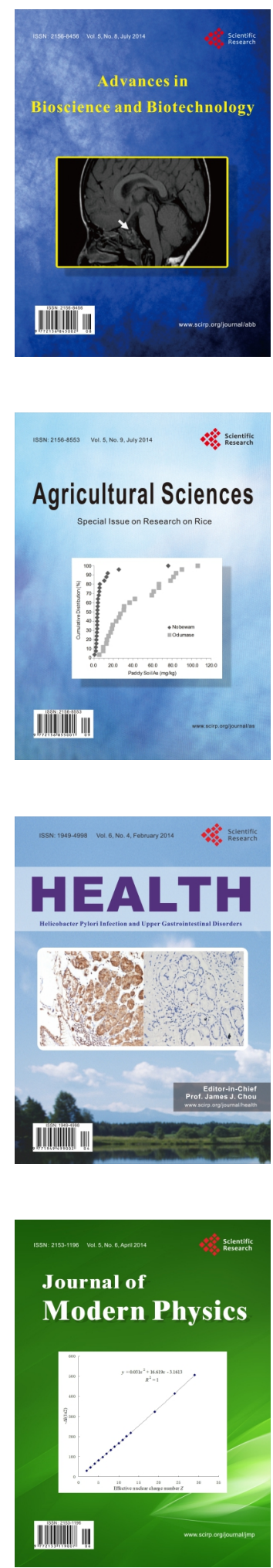
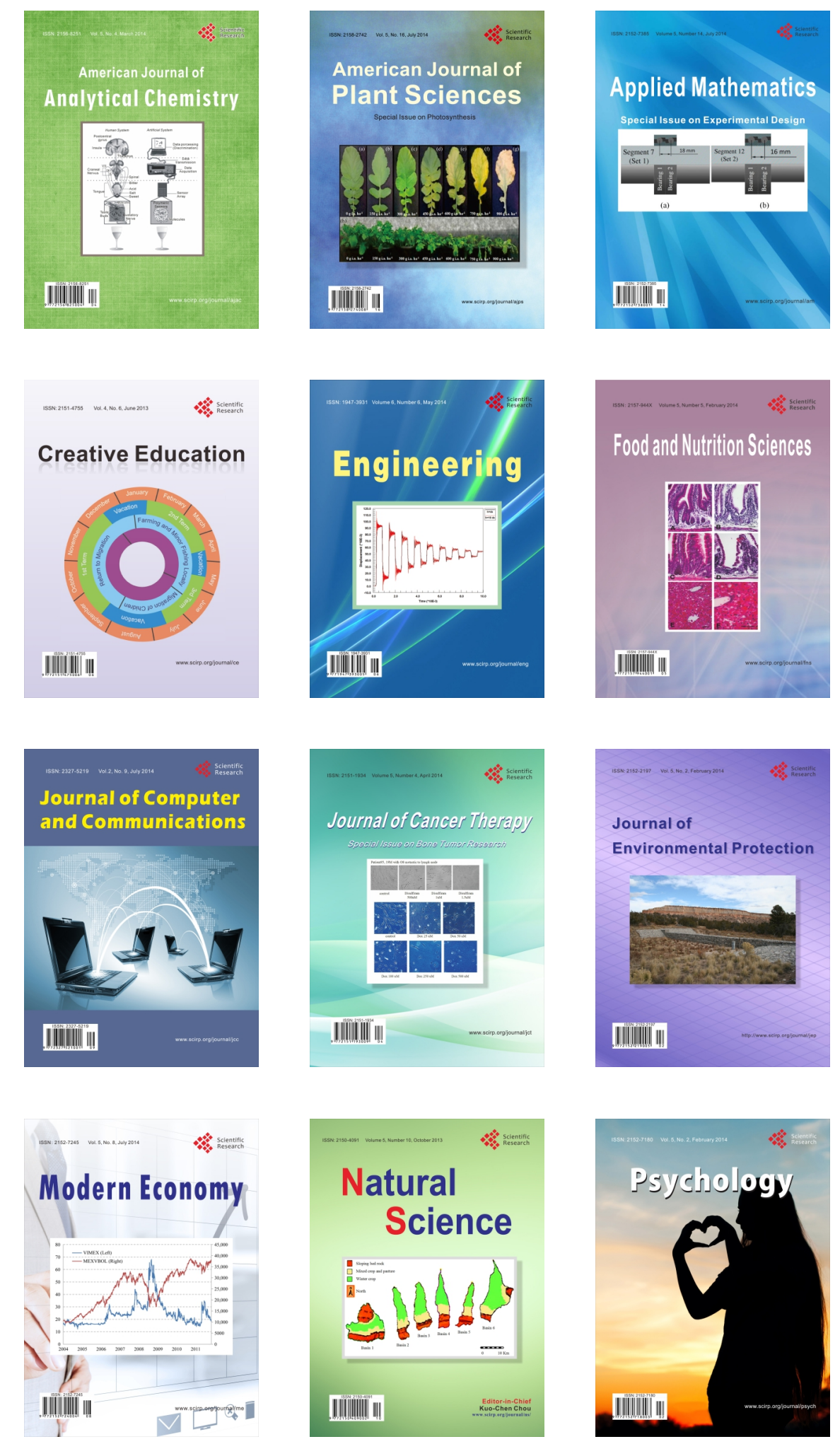